\title{
Forcepsioneura machadorum (Coenagrionidae: Protoneurinae) sp. nov. from the Cerrado Biome of Minas Gerais, southeastern Brazil
}

\author{
Diogo Silva Vilela (Di* ${ }^{\mathrm{a}}$, Henrique Venâncio (iD ${ }^{\mathrm{b}}$ and Jean Carlos Santos (iD) ${ }^{\mathrm{c}}$ \\ ${ }^{a}$ Rua Jaime Bilharinho, 575, CEP 38065-280, Uberaba, Minas Gerais, Brazil; ${ }^{b}$ Programa de \\ Pós-Graduação em Entomologia, Faculdade de Filosofia, Ciências e Letras de Ribeirão Preto, \\ Universidade de São Paulo, Ribeirão Preto, São Paulo, Brazil; ${ }^{c}$ Departamento de Ecologia, Universidade \\ Federal de Sergipe, São Cristóvão, Sergipe, Brazil
}

(Received 4 August 2020; final version received 31 August 2020)

\begin{abstract}
The Neotropical genus Forcepsioneura is composed of 11 species that inhabit almost exclusively the Brazilian Atlantic Forest domain, with F. sancta (Hagen in Selys, 1860) being the only species of this genus known to occur in the Cerrado biome. Here we describe a new species of Forcepsioneura from the Cerrado of Minas Gerais State, Brazil. This new species is morphologically closer to $F$. sancta and can be separated from this and other species of Forcepsioneura mainly by the rectangular shape of male prothoracic hind lobe and cerci morphology
\end{abstract}

http://www.zoobank.org/urn:1sid:zoobank.org:pub:5706455E-92F5-44C3-AD13-820F4B5131AE

Keywords: Odonata; damselfly; dragonfly; gallery forest; Brazilian Savanna

\section{Introduction}

The genus Forcepsioneura was proposed by Lencioni in 1999 to include species with male cercus presenting an internal apophysis (mediobasal process) and a vertically directed branch (ventrobasal process), a character combination which he proposed to differentiate Forcepsioneura from Phasmoneura species.

Since its recognition, Forcepsioneura has received much attention in relation to its taxonomy, with two species being transferred from Phasmoneura (Lencioni, 1999), a recently published revision (Pimenta, Pinto, \& Takiya, 2019), and many recently described species to the genus, which now is composed by 11 valid taxa: Forcepsioneura gabriela Pimenta, Pinto \& Takiya, 2019, F. garrisoni Lencioni, 1999, F. grossiorum Machado, 2005, F. haerteli Machado, 2001, F. itatiaiae (Santos, 1970), F. janeae Pimenta, Pinto \& Takiya, 2019, F. lopii Pinto \& Araujo, 2020, F. lucia Machado, 2000, F. regua Pinto \& Kompier, 2018, F. sancta (Hagen in Selys, 1860) and F. serrabonita Pinto \& Kompier, 2018.

Of these 11 species, only F. sancta is hitherto known to occur in the Cerrado Biome of Brazil, and all 10 other species are restricted to the Brazilian Atlantic Forest domain

\footnotetext{
*Corresponding author. Email: deeogoo@gmail.com 


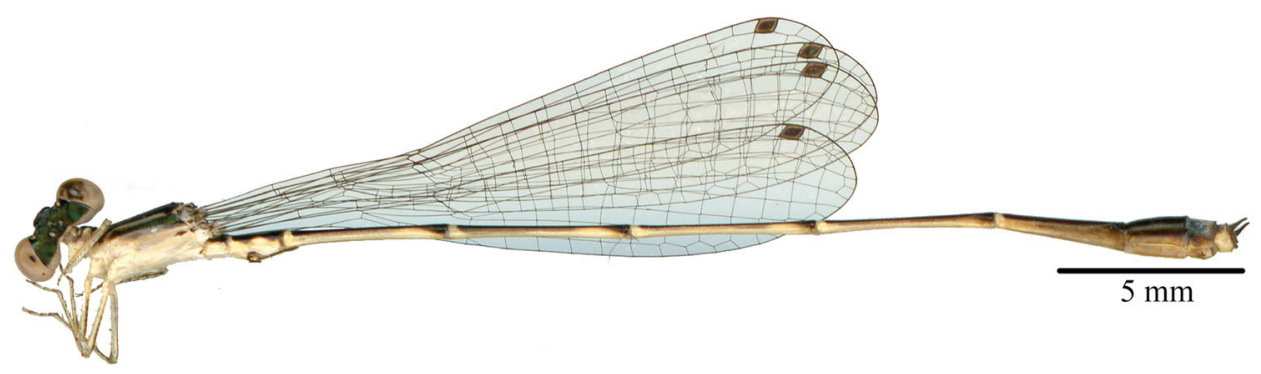

Figure 1. Forcepsioneura machadorum: male holotype lateral view of habitus.

(Pimenta et al., 2019). Here we describe a new species of Forcepsioneura, collected in a small forested area, representing the second species in the genus to be recorded within the Cerrado Biome of Brazil.

\section{Materials and methods}

Specimens were collected in the field with the aid of an entomological net, placed in rectangular envelopes, frozen for 12 hours and fixed with absolute ethanol before drying. Habitus of holotype and paratypes was scanned with an Epson V600 (Epson America, Long Beach, CA) Perfection at colored 1200 dpi with 200\% magnification. Structure images were made from multiple photographs focused at different levels, using a Canon EOS T3i (CANON USA Inc., NY, USA) digital camera coupled to E-Zoom 6 V stereomicroscope (Edmund Optics (Barrington, NJ, USA)). Free hand illustrations were made using trace paper and scanned with an Epson V600 Perfection at black and white 1200 dpi with $100 \%$ magnification. Illustrations 2 b, 3b, c, e and g were made by Rosser W. Garrison.

Morphological terminology follows Lencioni (1999), Garrison, von Ellenrieder, and Louton (2010) and Pinto \& Kompier (2018). All measurements are in millimeters (mm).

Abbreviations: Fw: fore wings; GL: genital ligula; Hw: hind wings; L1: segment 1 of genital ligula; L2: segment 2 of genital ligula; MBP: mediobasal process; MP: media posterior vein; Px: postnodal crossvein; Pt: pterostigma; RP2: radius posterior, second branch; S1-10: abdominal segments; VBP: ventrobasal process.

Acronyms for the collections are as follows:

FAAL, Frederico A. A. Lencioni Collection, Jacareí, São Paulo, Brazil; LESTES, Laboratory of Ecological Studies on Ethology and Evolution (LESTES), UFSCar, São Carlos, Brazil; LEBIO, Laboratory of Ecology and Biodiversity (LEBIO), UFS, São Cristóvão, Sergipe, Brazil.

\section{Taxonomy}

Family Coenagrionidae Kirby, 1890

Subfamily Protoneurinae Yakobson \& Bianchi, 1905

Genus Forcepsioneura Lencioni, 1999

Forcepsioneura machadorum sp. n. Vilela, Venâncio \& Santos

(Figures 1, 2a, c, 3a, d, f)

\section{Etymology}

Named machadorum (noun in the plural genitive case) as a sincere homage to Prof. Dr. Ângelo Barbosa Monteiro Machado (1934-2020) for his countless contributions to literature, music, and 


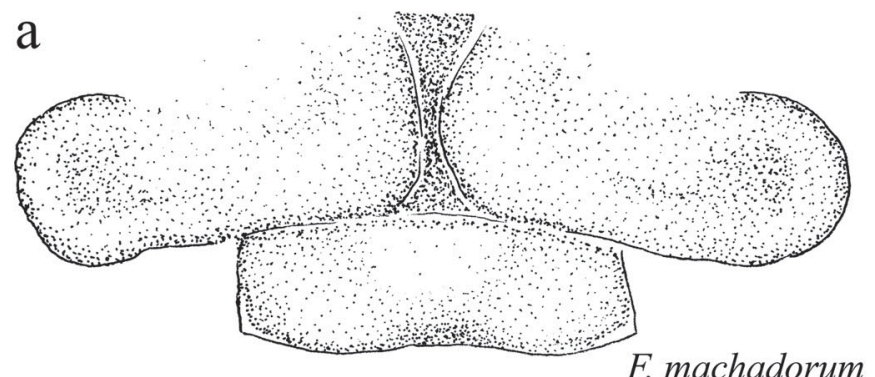

b
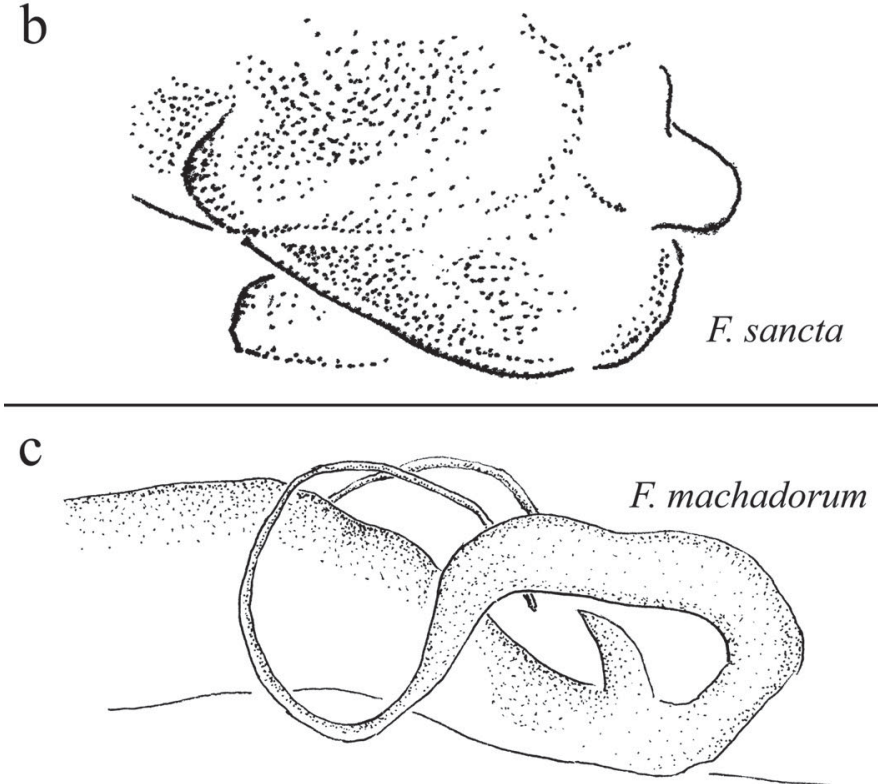

Figure 2. Forcepsioneura machadorum: male holotype dorsal view of prothorax (a) and genital ligula (c); Forcepsioneura sancta: male dorsolateral view of prothorax (b).

sciences, especially in odonatology, his wife Prof. Conceição Machado (1936-2007) who along with Prof. Ângelo performed several studies on the human autonomic nervous system, mainly on the pineal gland, and their family (children and grandchildren) whom they very much loved.

\section{Type specimens}

Holotype $\sigma^{7}$ : Brazil, Uberlândia, Universidade Federal de Uberlândia - Fazenda Experimental do Glória (18.9572 S, 48.2091 N, 860 m asl), 2 September 2019, H. Venâncio leg.; - Paratypes: 4o', same data as holotype, except for: $2 \sigma^{\top}$ collected 10 October 2019 and $2 \sigma^{\top}$ collected 11 October 2019.

\section{Type specimen deposition}

Holotype and one paratype are deposited at LESTES, two paratypes are deposited at FAAL and one paratype is deposited at LEBIO. 


\section{Diagnosis}

Forcepsioneura machadorum can be separated from F. sancta and its other congeners by the rectangular shape of the prothoracic hind lobe and the morphology of cerci.

\section{Description of holotype male}

Head (Figure 1). Labium, mandible and genae pale colored; anteclypeus dark brown with a pale spot at the center; postclypeus dark brown; antefrons light green; frons and epicranium metallic dark green, except for a longitudinal pale dorsal stripe along postocular and occipital areas; antennifer dark brown with a pale ring at the apex; antenna dark brown, except for pale coloration on the posterior surface of pedicel; rear of the head pale colored, except for two brown spots on each side of the occipital foramen and a longitudinal light grey stripe on the upper portion.

Thorax (Figures 1, 2a). Anterior lobe of prothorax dark brown, becoming paler laterally; medial lobe dark brown except for light brown and pale areas in the propleuron and tubercle; posterior lobe dark brown; medial lobe with two lateral tubercles (cone-like viewed laterally, digit-like viewed dorsally); hind lobe rectangular with a slightly concave medial depression, with posterolateral corners forming right angles (Figure 2a). Pterothorax with mesepisternum and mesepimeron metallic green, except for a light green stripe on the interpleural suture; metepisternum and metepimeron pale colored except for a darker thin stripe at the upper posterior portion of metepimeron and a dark spot on the posterior metepisternum/metepimeron suture; venter pale.

Legs (Figure 1). Overall coloration pale, armature brown, femoral-tibial and tarsal articulations brown; spurs light brown.

Wings (Figure 1). Hyaline; venation dark brown; Pt dark brown with pale contours; MP reaches anal margin 0.3 cell distal to vein descending from subnodus; RP2 originating at Px 5 in $\mathrm{Fw}$, at $\mathrm{Px} 4$ in Hw; $11 \mathrm{Px}$ in Fw, $9 \mathrm{Px}$ in Hw.

Abdomen (Figure 1). Tergites S1 - 10 dark brown dorsally, S1 - 7 and S10 pale laterally, S89 dark brown laterally; sternites S1 - 5 and S10 pale, S6-9 dark brown; S3-7 with a pale basal ring, S3-6 with a dark brown apical ring; S9-10 dorsally covered with a thin layer of white pruinosity; anterior lamina rectangular with acute corners, anterior hamule roughly squared with a slight excavation on the anterior portion, culminating in an acute apex anteroventrally; posterior hamule a thin "I"-shaped structure bearing several small setae (only visible ventrally).

Genital ligula (Figure 2c). L1 smooth, without apparent setae; in lateral view, internal fold roughly triangular, oblique, long, almost reaching the segment above; in ectal view, flexure with a slight concavity; in ectal view, distal margin of L2 rectangular, flat, with only a smooth concavity; flagellae long, curved, flat and wide in their proximal portion, becoming cylindrical and thin towards their apex.

Anal appendages (Figures 1, 3a, d, f). Basal portion light brown, remainder black with a blunt tip; in dorsal view cerci are forcipate, widest at base, gradually tapering distally, with converging apexes; in lateral view directed obliquely dorsad (Figure 3a); VBP light brown, with a black tip; in lateral view long, forming a right angle with dorsal branch, distal portion almost at ventral level of S10, apex rounded (Figure 3a); apexes acute and curved inward (almost touching each other) in posterior view (Figure 3d); MBP not seen in lateral view; in dorsolateral view digit-like with a rounded apex (Figure 3f); in posterior view cylindrical with a blunt apex, horizontally oriented, and about 0.5 the length of VBP (Figure 3d); paraproct pale colored, plate-like with a medial finger-like structure.

Measurements. Total 30.7; abdomen 26.2; head width 3; Fw 18.3, Hw 17.2; Pt 0.5; metathoracic femur 1.9; metathoracic tibia 1.7; cercus 0.56 ; VBP 0. ; cercus/VBP ratio 0.71 ; S9 +101.1 . 

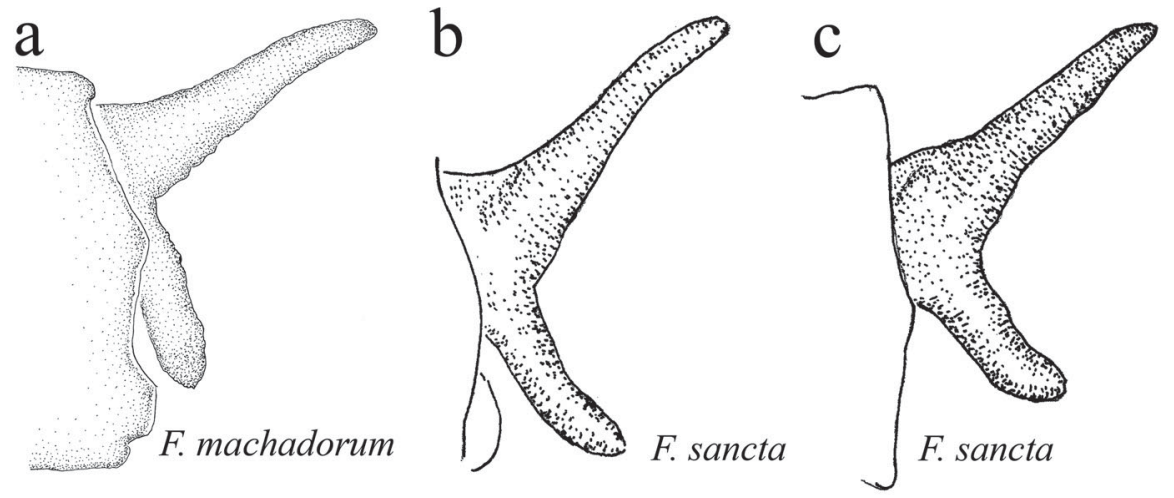

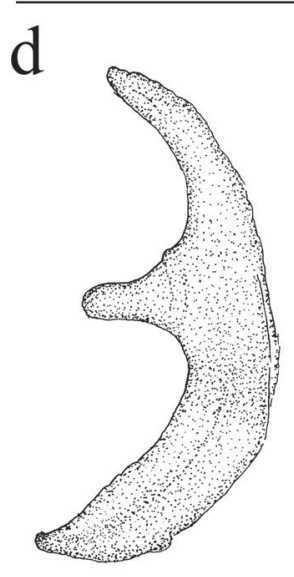

F. machadorum

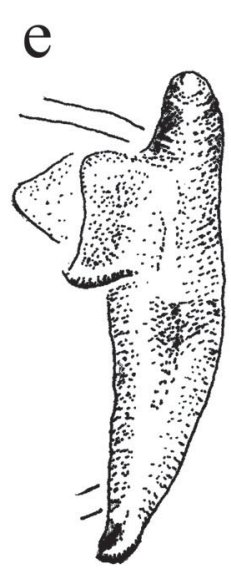

F. sancta

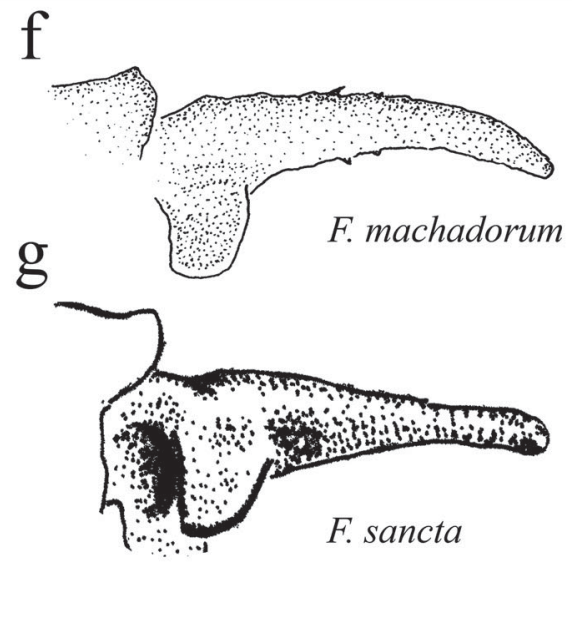

Figure 3. Forcepsioneura machadorum: male holotype cercus in lateral (a), posterior (d) and dorsolateral (f) views; Forcepsioneura sancta: male cercus in lateral (b, c), posterior (e) and dorsolateral (g) views.

Variation in paratypes. Overall coloration of paratypes similar to the holotype, except for dark spot on the posterior metepisternum/metepimeron suture which is less evident in two paratypes, and one paratype (perhaps a younger one) lacking pruinosity on S9-10. Other observed variations are as follows: MP reaches anal margin 0.5 cell distal to the vein descending from subnodus in three paratypes; $10 \mathrm{Px}$ in Fw, $8 \mathrm{Px}$ in Hw in three paratypes.

Measurements (range followed by standard deviation in parenthesis). Total 30.4-31.6 ( \pm 0.69 ); abdomen 25.2-26.3 ( \pm 0.56 ); head width 2.8-3 ( \pm 0.1$)$; Fw 17.4-17.9 ( \pm 0.2$)$, Hw 16.4-17 ( \pm 0.4$)$; Pt $0.5( \pm 0)$; metathoracic femur 1.86-2 $( \pm 0.08)$; metathoracic tibia $1.8( \pm$ $0)$; cercus $0.49-0.54( \pm 0.05)$; VBP $0.3-0.35$ ( \pm 0.02$)$; cercus/VBP ratio $0.61-0.7$ ( \pm 0.05 ); $\mathrm{S} 9+101-1.1( \pm 0.05)$.

\section{Habitat and ecology}

The type locality of Forcepsioneura machadorum is located in a small forested area inside a satellite campus of the Universidade Federal de Uberlândia, Fazenda Experimental do Glória (Figure 4). At this locality, the new species was found along a small spring inside a gallery forest. At the same place there are also remnants of Cerrado/semi-deciduous forest ecotone (Figure 5). 


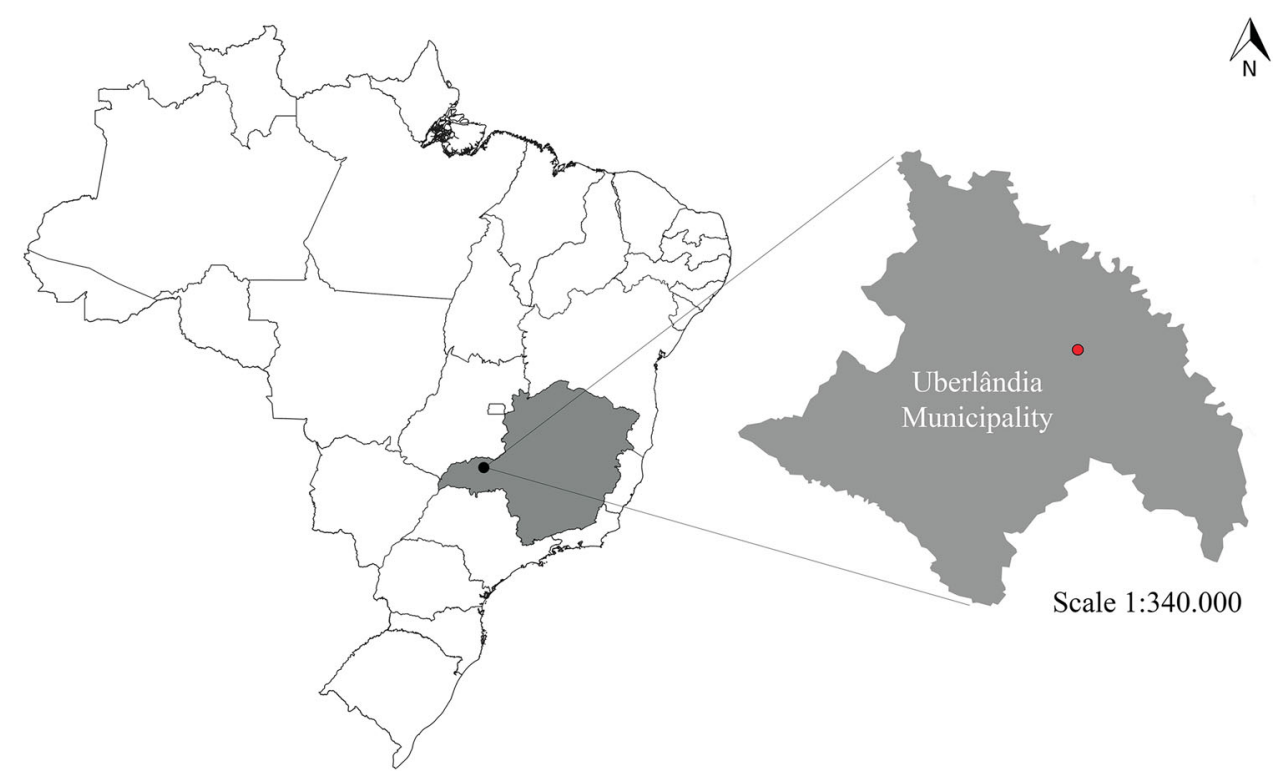

Figure 4. Type locality map of Forcepsioneura machadorum (red dot) within Uberlândia municipality in Minas Gerais, Brazil.

\section{Differential diagnosis}

Within Forcepsioneura, considering the length of MP vein in Hw, cercus/VBP ratio, apex of VBP and shape of MBP, F. machadorum is similar to F. sancta. However, the following combination of characters allows for a good differential diagnosis between the two species: while in F. sancta the hind prothoracic lobe is rounded (as in Figure 2b), in F. machadorum this structure is squared with a slightly shallow medial depression, with right-angled posterolateral corners (Figure 2a); in posterior view, the MBP of $F$. sancta appears as a squared basal plate ending in a blunt apex (Figure 3e), whereas in F. machadorum the MBP lacks a basal plate, and is cylindrical with a blunt apex (Figure 3d); in dorsolateral view, MBP is digit-like with rounded apex in F. machadorum (Figure 3f), whereas in $F$. sancta the apex is bluntly pointed at its anteromesal corner (Figure $3 \mathrm{~g}$ ). Other characteristics of $F$. sancta and $F$. machadorum can be used secondarily in order to differentiate them, such as body coloration: in F. machadorum there is a light green stripe on the interpleural suture, which in some individuals of $F$. sancta is absent or dark brown, depending on the individual age; the longitudinal pale dorsal stripe covering postocular and occipital areas in F. machadorum also seems to be absent in F. sancta.

\section{Discussion}

Forcepsioneura machadorum is the third species of the genus known to occur in the State of Minas Gerais, in addition to F. lucia and F. sancta (Lencioni, 2017; Machado, 2000), and the second one recorded from the Cerrado Biome (Pimenta et al., 2019). Including this new species, there are 297 recorded species in Minas Gerais State according to the literature (Vilela, 2020).

This new species was collected inside a satellite campus of the Universidade Federal de Uberlândia in a small protected forested area. A few meters inside this patch of vegetation there is a spring from which a small stream runs among the trees. This highlights the importance of the preservation of these areas and also encourages sampling efforts on forest remnants because 

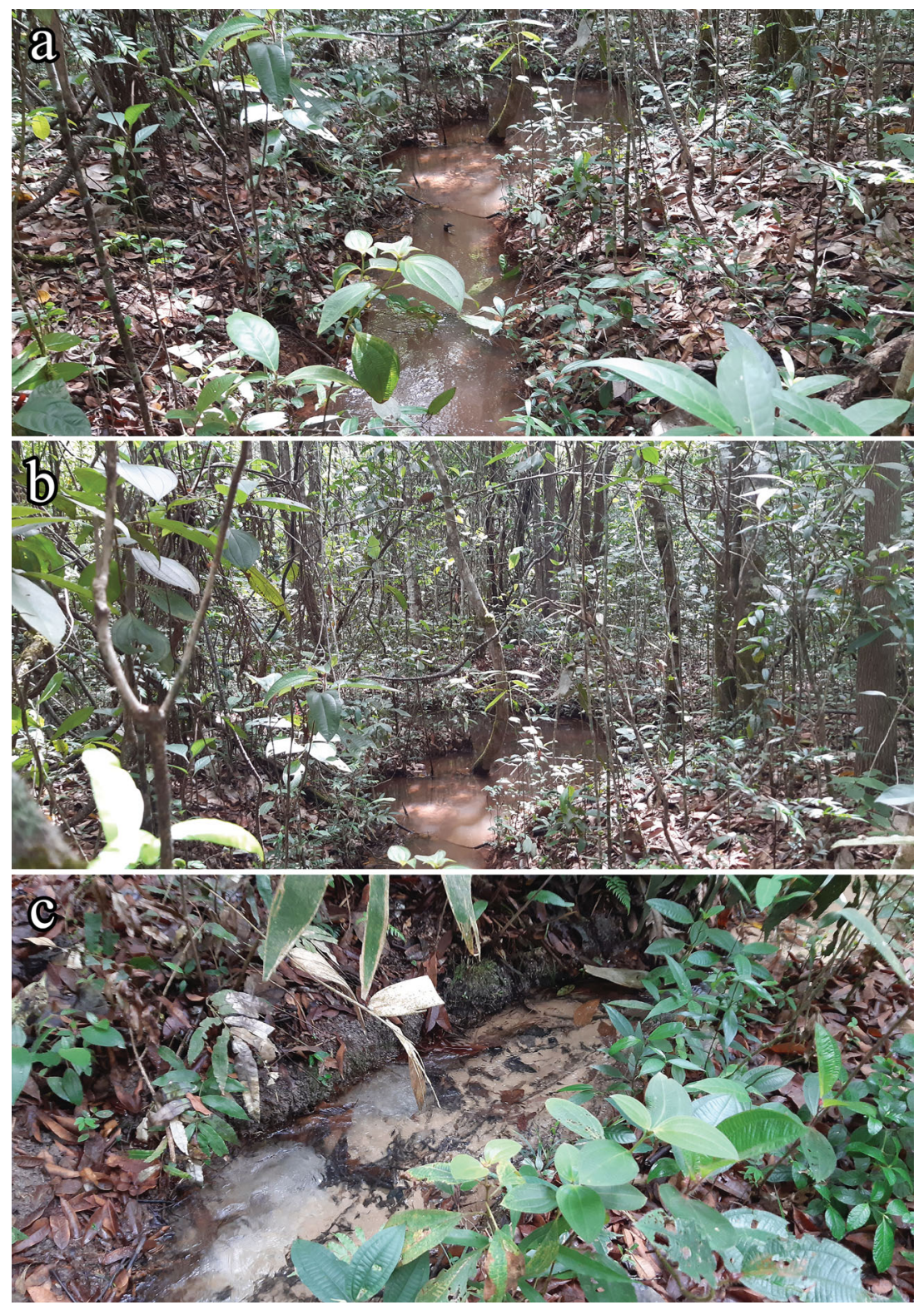

Figure 5. $(\mathrm{a}-\mathrm{c})$ Type locality of Forcepsioneura machadorum: a small sandy-bottomed stream among the trees.

even though it is an area with a certain degree of anthropic activity, it holds several odonate populations inside, including Angelagrion sp., Acanthagrion truncatum Selys, 1876, Heliocharis amazona Selys, 1853, Homeoura lindneri (Ris, 1928), Protoneura tenuis Selys, 1860, Oxyagrion chapadense Costa, 1978, and Epipleoneura williamsoni Santos, 1957.

\section{Acknowledgements}

We thank Frederico Lencioni for confirming the novelty of our specimens, Rosser W. Garrison for helping with images, illustrations and suggestions, Natalia von Ellenrieder and Pablo Pessacq for critically reviewing this manuscript. We also thank Federal University of Uberlândia for allowing us to work in the study area. 


\section{Funding}

Conselho Nacional de Desenvolvimento Científico e Tecnológico (Process 140158/2018-9); JCS acknowledges their research grants by CNPq (JCS grant process \#312752/2018-0).

\section{ORCID}

Diogo Silva Vilela (D) http://orcid.org/0000-0001-6510-7018

Henrique Venâncio (iD http://orcid.org/0000-0001-9924-0212

Jean Carlos Santos (D) http://orcid.org/0000-0001-6031-9193

\section{References}

Garrison, R. W., von Ellenrieder, N., \& Louton, J. A. (2010). Damselfly genera of the New World: An illustrated and annotated key to the Zygoptera. Baltimore, MD: The Johns Hopkins University Press.

Lencioni, F. A. A. (1999). The genus Phasmoneura, with description of Forcepsioneura gen. nov. and two new species (Zygoptera: Protoneuridae). Odonatologica, 28(2), 127 - 137. Retrieved from http://natuurtijdschriften.nl/search? identifier $=592273$

Lencioni, F. A. A. (2017). Damselflies of Brazil - An illustrated identification guide - Southeast Region [E-book]. São Paulo: Jacareí.

Machado, A. B. M. (2000). Studies on neotropical Protoneuridae 10 Forcepsioneura lucia sp. n. from the Parque Estadual Rola Moça, Minas Gerais, Brazil (Odonata, Zygoptera). Boletim do Museu de Biologia Mello Leitão, 11/12, 127 - 134. Retrieved from http://boletim.sambio.org.br/pdf/11_07.pdf

Pimenta, A. L. A., Pinto, Â. P., \& Takiya, D. M. (2019). Integrative taxonomy and phylogeny of the damselfly genus Forcepsioneura Lencioni, 1999 (Odonata: Coenagrionidae: Protoneurinae) with description of two new species from the Brazilian Atlantic Forest. Arthropod Systematics \& Phylogeny, 77(3), 397 - 415. https://doi.org/10.26049/ASP77-3-2019-2

Pinto, A. P., \& Kompier, T. (2018). In honor of conservation of the Brazilian Atlantic Forest: description of two new damselflies of the genus Forcepsioneura discovered in private protected areas (Odonata: Coenagrionidae). Zoologia (Curitiba), 35, 1 - 19. https://doi.org/10.3897/zoologia.35.e21351

Vilela, D. S. (2020). Libélulas de Minas Gerais [Data set]. Retrieved August 1, 2020 from: http://libelulasdemg.com.br/ 